\title{
Immunoadsorption: A New Strategy to Induce Remission in Membranous Lupus Nephritis
}

\author{
Tim Ulinski $^{a, b} \quad$ Aurélie Davourie-Salandre $^{a, b} \quad$ Isabelle Brocheriou ${ }^{b, c}$ \\ Bilal Aoun ${ }^{a}$ \\ ${ }^{a}$ Department of Pediatric Nephrology, APHP, DHU i2B Inflammation-Immunopathology- \\ Biotherapy, Armand-Trousseau Hospital, ${ }^{b}$ University Pierre and Marie Curie, and \\ 'Department of Pathology, Tenon Hospital, APHP, Paris, France
}

\section{Key Words}

Membranous lupus nephritis · Immunoadsorption · Rituximab · Proteinuria

\begin{abstract}
We report the case of an 11-year-old previously healthy girl who presented for microscopic hematuria and nephrotic proteinuria with normal renal function, which persisted after 6 months of steroids, angiotensin-converting enzyme inhibitors (ACEi)/angiotensin receptor blockers, hydroxychloroquine, mycophenolic acid and a low-salt diet. A serum investigation suggested lupus nephritis and a renal biopsy, performed 2 weeks after the first proteinuria detection, revealed membranous lupus nephritis. We decided to perform ten sessions of daily immunoadsorption. Proteinuria decreased significantly over these ten sessions from 8 to $0.12 \mathrm{~g} / \mathrm{l}$. After the tenth immunoadsorption session, the patient received the first rituximab (RTX) infusion leading to complete B-cell depletion. The patient was maintained on ACEi associated with mycophenolic acid and hydroxychloroquine. Three RTX reinjections were performed when CD19-positive cells reappeared in peripheral blood. Despite complete B-cell recovery and positive anti-dsDNA-Ab, the patient remained in complete remission 18 months after the initial diagnosis with negative proteinuria and a normal renal function.
\end{abstract}

(c) 2014 S. Karger AG, Basel

\section{Introduction}

Membranous glomerulonephritis accounts for $20 \%$ of all cases of adult lupus nephritis [1]. Lupus membranous nephritis (MN) is relatively rare in children [2,3]. Histologically, it is 
characterized by subepithelial immune deposits along the peripheral capillary loops leading to uniform thickening of the glomerular capillary wall. Immunofluorescence shows subepithelial and often concomitant mesangial immune deposits. MN presents with various clinical signs ranging from nephrotic syndrome (NS) to asymptomatic proteinuria. In most cases, proteinuria is nonselective and associated with microscopic hematuria. Hypertension is present in a small subset of patients [1].

In children, MN is responsible of 5\% of cases of primary NS, while in adults it is considered a main cause of NS $[1,2]$. Histologically, MN is characterized by the uniform thickening of the glomerular capillary wall on light microscopy. The latter thickening is associated with subepithelial immune complex deposits that appear as granular deposits of immunoglobulin $G$ on immunofluorescence. Recently two target antigens have been discovered, neutral endopeptidase [4] and type-M phospholipase A2 receptor (PLA2R) [5]. PLA2R is the first autoantigen identified in idiopathic membranous nephropathy in adults. This provides new tools for monitoring disease activity and should help designing new antigen-driven therapeutic strategies in the future.

MN can manifest in a clinical setting of lupus nephritis, hepatitis B, Epstein Barr virus and others [1, 6-8]. Other rare causes have been described including C4 complement deficiency and antitubular basement membrane antibodies [9].

The treatment algorithm for managing $\mathrm{MN}$ in adults relies on assessing the prognostic factors at illness onset and trying to achieve a balance between the probability of renal failure and the risk of immunosuppression. Since MN is rare in the pediatric age group, no standardized approach to therapy in children has been identified $[2,7]$. Patients with lupus MN present with proteinuria and hematuria up to NS. Patients are frequently treated with angiotensin-converting enzyme inhibitors (ACEi) and angiotensin receptor blockers (ARB), and often with a low-salt diet or thiazide diuretics. Other protocols have been proposed including short steroid therapy, more potent immunosuppressive drugs like cyclophosphamide, mycophenolic acid, calcineurin inhibitors, and B-cell depleting agents, but controlled studies are rare [10-17] despite existing guidelines from the KDIGO [18], ERA/EDTA [19] and ACR [20]. Specific pediatric recommendations do not exist.

The use of immunoadsorption has been considered in several autoimmune diseases, but still studies are lacking in the pediatric and adolescent age group.

\section{Case Report}

We report the case of an 11-year-old previously healthy girl $(36 \mathrm{~kg}, 151 \mathrm{~cm})$ who presented to the emergency room for nephrotic proteinuria and microscopic hematuria found on routine dipstick examination. The patient was afebrile, without edemas. Initially analysis showed a serum creatinine of $42 \mu \mathrm{mol} / \mathrm{l}$, with a total serum protein of $62 \mathrm{~g} / \mathrm{l}$. Three weeks later, the patient had palpebral edema, initially considered as an allergic manifestation and treated by antihistamine medication for 2 weeks. Therefore, total serum protein levels decreased to $46 \mathrm{~g} / \mathrm{l}$ and albumin was $11 \mathrm{~g} / \mathrm{l}$, with a proteinuria of $12 \mathrm{~g} / \mathrm{l}$. Vital signs were normal with a blood pressure of $123 / 76 \mathrm{~mm} \mathrm{Hg}$.

The patient was initially treated as idiopathic NS with daily oral prednisone therapy (60 $\mathrm{mg} / \mathrm{m}^{2}$ ) for 1 month. Immunological investigations showed elevated antinuclear antibodies $(>1 / 640)$, positive anti-Smith antibodies, and positive anti-ribonuclear antibodies, with a normal complement including C3 (1,090 mg/l), C4 (321 mg/l), and CH50 (145\%). Serology for hepatitis B, C and HIV returned negative. Renal ultrasound showed well-differentiated kidneys of normal size. 
Kidney biopsy revealed histological lesions and immunofluorescence deposits compatible with membranous lupus nephritis. No vascular or tubulointerstitial fibrosis was found. The patient was started on ACEi (enalapril $20 \mathrm{mg}$ once daily), ARB (losartan $50 \mathrm{mg}$ once daily), mycophenolic acid (540 mg twice daily), and hydroxychloroquine (200 mg daily).

Five months later, nephrotic proteinuria $(8 \mathrm{~g} / \mathrm{l})$ and hypoalbuminemia $(11 \mathrm{~g} / \mathrm{l})$ persisted. Therefore, we decided to perform ten sessions of daily immunoadsorption (TheraSorb Ig flex adsorbers, LIFE 18; Miltenyi Biotec GmbH, Teterow, Germany). Proteinuria decreased significantly over these ten sessions from 8 to $0.12 \mathrm{~g} / \mathrm{l}$ after session 8 (fig. 1). After the tenth immunoadsorption session, the patient received a first rituximab (RTX) infusion (375 $\mathrm{mg} / \mathrm{m}^{2}$ ). The initial CD19 and CD20 levels were $28 \%$ and became $0 \%$ at 6 days after the RTX injection. The patient was maintained on ACEi and thiazide diuretics associated with hydroxychloroquine and mycophenolic acid. Three RTX reinjections were performed at 375 $\mathrm{mg} / \mathrm{m}^{2}$ after 3,5 and 7 months, respectively, when CD19-positive cells recovered in peripheral blood (13,12 and $17 \%$, respectively).

Despite complete B-cell recovery and positive anti-dsDNA-Ab, the patient remained in complete remission 24 months after the initial diagnosis; she has negative proteinuria and a normal serum creatinine of $37 \mu \mathrm{mol} / \mathrm{l}$. During the whole follow-up period, the patient was maintained on ACEi, mycophenolic acid and hydroxychloroquine.

\section{Discussion}

Lupus nephritis remains the most common severe manifestation of systemic lupus erythematosus characterized by the presence of autoantibodies (Abs) that are believed to play a central role in its pathogenesis. Among more than $100 \mathrm{Abs}$ reported in systemic lupus erythematosus, only a few display a direct glomerular binding capacity. Such antiglomerular Abs are detected at the onset of the disease generally before the detection of antinuclear Abs. Antiglomerular Abs encompass anti- $\alpha$-actinin, anti-laminin- 1 , antifibronectin, antimyosin and anticollagen Abs.

Extracorporeal immunoadsorption is a method to remove such circulating antibodies mainly, thus potentially reducing the antibody-kidney deposition and proteinuria [21]. Data on membranous lupus nephritis in children are rare. Long-term prognosis in class 5 lupus nephritis patients depends on treatment response [22, 23]. Corticosteroid treatment seems to be of relatively low efficiency and its indication in pure class 5 lupus nephritis is strongly questioned today as long as there is no proliferative lesion associated to MN.

Our patient had initially normal complement C3 and C4 levels, but anti-nuclear Abs were initially present and anti-dsDNA-Abs were initially negative and were positive 1 month later. They remained positive during the whole B-cell depletion period. However, proteinuria changed from nephrotic range to negative after ten daily immunoadsorption sessions.

If specific lupus antibodies are believed to be involved in the pathomechanism of proteinuria in membranous lupus nephritis, it is surprising that proteinuria became rapidly negative after introduction of immunoadsorption while anti-ds-DNA Abs were still present during and after immunoadsorption and during B-cell depletion. Therefore, one may hypothesize that other Abs not related to anti-DNA might have played a role in disease activity.

In conclusion, it seems that immunoadsorption can help to reduce proteinuria safely in patients with membranous lupus nephritis and persistent nephrotic range proteinuria despite several months of ACEi/ARB, mycophenolic acid and hydroxychloroquine treatment. Negative proteinuria at the time of RTX injection may increase RTX bioavailability. 


\begin{tabular}{l|l}
\hline \multicolumn{2}{l}{ Case Rep Nephrol Urol 2014;4:37-41 } \\
\hline DOI: 10.1159/000361014 & $\begin{array}{l}\text { ○ 2014 S. Karger AG, Basel } \\
\text { www.karger.com/cru }\end{array}$ \\
\hline
\end{tabular}

Ulinski et al.: Immunoadsorption: A New Strategy to Induce Remission in Membranous Lupus Nephritis

\section{References}

1 Austin HA, Illei GG: Membranous lupus nephritis. Lupus 2005;14:65-71.

2 Nathanson S, Salomon R, Ranchin B, Macher MA, Lavocat MP, Krier MJ, Baudouin V, Azema C, Bader-Meunier B, Deschenes G: Prognosis of lupus membranous nephropathy in children. Pediatr Nephrol 2006;21:11131116.

-3 Niaudet P: Treatment of lupus nephritis in children. Pediatr Nephrol 2000;14:158-166.

$\checkmark 4$ Debiec H, Guigonis V, Mougenot B, Decobert F, Haymann JP, Bensman A, Deschenes G, Ronco PM: Antenatal membranous glomerulonephritis due to anti-neutral endopeptidase antibodies. N Engl J Med 2002;346:2053-2060.

5 Debiec H, Ronco P: PLA2R autoantibodies and PLA2R glomerular deposits in membranous nephropathy. N Engl J Med 2011;364:689-690.

-6 Cramer CH 2nd, Mills M, Valentini RP, Smoyer WE, Haftel H, Brophy PD: Clinical presentation and outcome in a cohort of paediatric patients with membranous lupus nephritis. Nephrol Dial Transplant 2007;22:3495-3500.

7 Chen A, Frank R, Vento S, Crosby V, Chandra M, Gauthier B, Valderrama E, Trachtman H: Idiopathic membranous nephropathy in pediatric patients: presentation, response to therapy, and long-term outcome. BMC Nephrol 2007;8:11.

8 Mercadal L, Montcel ST, Nochy D, Queffeulou G, Piette JC, Isnard-Bagnis C, Martinez F: Factors affecting outcome and prognosis in membranous lupus nephropathy. Nephrol Dial Transplant 2002;17:1771-1778.

-9 Levy M, Gagnadoux MF, Beziau A, Habib R: Membranous glomerulonephritis associated with anti-tubular and anti-alveolar basement membrane antibodies. Clin Nephrol 1978;10:158-165.

10 Davies RJ, Sangle SR, Jordan NP, Aslam L, Lewis MJ, Wedgwood R, D'Cruz DP: Rituximab in the treatment of resistant lupus nephritis: therapy failure in rapidly progressive crescentic lupus nephritis. Lupus 2013;22:574-582.

11 Bomback AS, Appel GB: Updates on the treatment of lupus nephritis. J Am Soc Nephrol 2010;21:2028-2035.

12 Mok CC: Membranous nephropathy in systemic lupus erythematosus: a therapeutic enigma. Nat Rev Nephrol 2009;5:212-220.

13 Beck LH Jr, Salant DJ: Treatment of membranous lupus nephritis: where are we now? J Am Soc Nephrol 2009;20:690-691.

14 Szeto CC, Kwan BC, Lai FM, Tam LS, Li EK, Chow KM, Gang W, Li PK: Tacrolimus for the treatment of systemic lupus erythematosus with pure class V nephritis. Rheumatology (Oxford) 2008;47:1678-1681.

15 Fujinaga S, Ohtomo Y, Umino D, Mochizuki H, Takemoto M, Shimizu T, Yamashiro Y, Kaneko K: Treatment of steroid-resistant membranous lupus nephritis with plasmapheresis and low-dose cyclosporine. Pediatr Nephrol 2007;22:616-617.

16 Waldman M, Appel GB: Update on the treatment of lupus nephritis. Kidney Int 2006;70:1403-1412.

17 Hallegua D, Wallace DJ, Metzger AL, Rinaldi RZ, Klinenberg JR: Cyclosporine for lupus membranous nephritis: experience with ten patients and review of the literature. Lupus 2000;9:241-251.

18 Radhakrishnan J, Cattran DC: The KDIGO practice guideline on glomerulonephritis: reading between the (guide)lines - application to the individual patient. Kidney Int 2012;82:840-856.

19 Bertsias GK, Ioannidis JP, Aringer M, Bollen E, Bombardieri S, Bruce IN, Cervera R, Dalakas M, Doria A, Hanly JG, Huizinga TW, Isenberg D, Kallenberg C, Piette JC, Schneider M, Scolding N, Smolen J, Stara A, Tassiulas I, Tektonidou M, Tincani A, van Buchem MA, van Vollenhoven R, Ward M, Gordon C, Boumpas DT: EULAR recommendations for the management of systemic lupus erythematosus with neuropsychiatric manifestations: report of a task force of the EULAR standing committee for clinical affairs. Ann Rheum Dis 2012;69:2074-2082.

20 Hahn BH, McMahon MA, Wilkinson A, Wallace WD, Daikh DI, Fitzgerald JD, Karpouzas GA, Merrill JT, Wallace DJ, Yazdany J, Ramsey-Goldman R, Singh K, Khalighi M, Choi SI, Gogia M, Kafaja S, Kamgar M, Lau C, Martin WJ, Parikh S, Peng J, Rastogi A, Chen W, Grossman JM: American College of Rheumatology guidelines for screening, treatment, and management of lupus nephritis. Arthritis Care Res (Hoboken) 2012;64:797-808.

21 Amital H, Heilweil-Harel M, Ulmansky R, Harlev M, Toubi E, Hershko A, Naparstek Y: Antibodies against the VRT101 laminin epitope correlate with human SLE disease activity and can be removed by extracorporeal immunoadsorption. Rheumatology (Oxford) 2007;46:1433-1437.

22 Sun HO, Hu WX, Xie HL, Zhang HT, Chen HP, Zeng CH, Liu ZH, Li LS: Long-term outcome of Chinese patients with membranous lupus nephropathy. Lupus 2008;17:56-61.

23 Moroni G, Quaglini S, Gravellone L, Gallelli B, Leoni A, Messa P, Sinico RA: Membranous nephropathy in systemic lupus erythematosus: long-term outcome and prognostic factors of 103 patients. Semin Arthritis Rheum 2012;41:642-651. 
Ulinski et al.: Immunoadsorption: A New Strategy to Induce Remission in Membranous

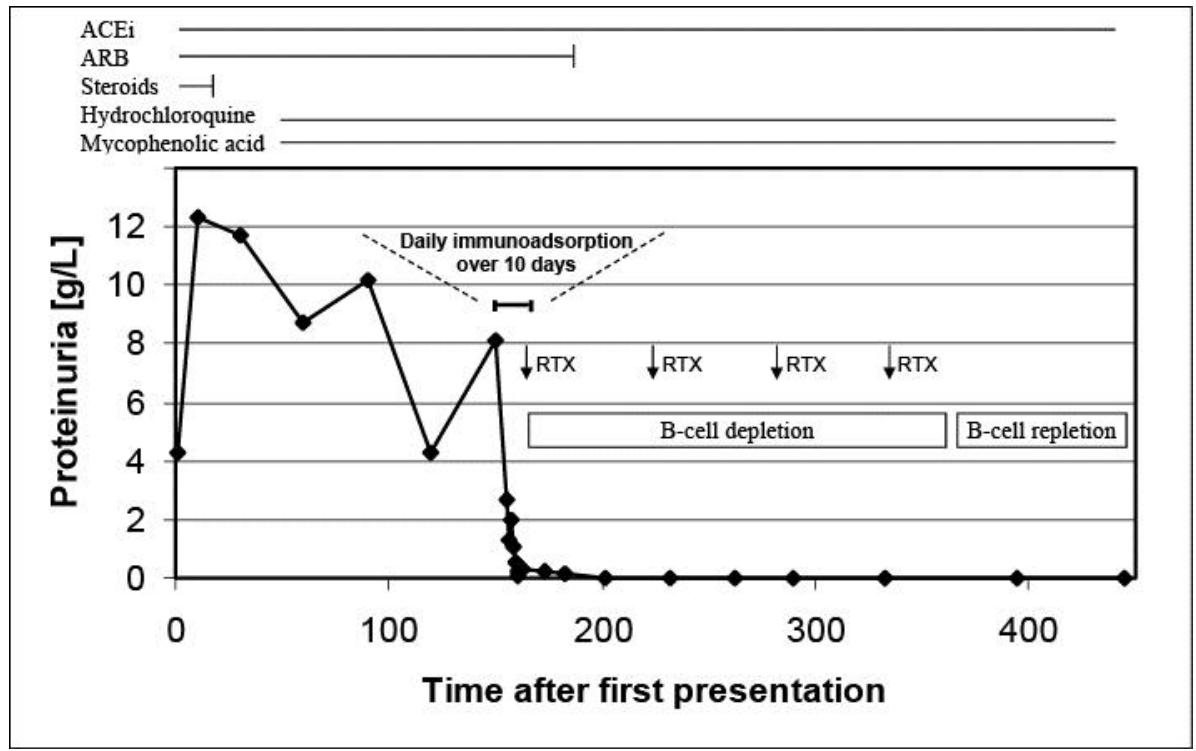

Fig. 1. Proteinuria changes during the disease course. The patient received ACEi (enalapril $20 \mathrm{mg}$ daily), ARB (losartan $50 \mathrm{mg}$ daily), mycophenolic acid (540 mg twice daily), hydroxychloroquine (200 mg daily), and RTX injections $\left(375 \mathrm{mg} / \mathrm{m}^{2}\right)$. 